\title{
Paideusis
}

\section{Is There Something to be Said for Getting No Respect? Comment on J.R. Coombs's "Respect for Law: An Educational Object?"}

\section{Richard Bronaugh}

Volume 1, Number 2, 1988

URI: https://id.erudit.org/iderudit/1073426ar

DOI: https://doi.org/10.7202/1073426ar

See table of contents

Publisher(s)

Canadian Philosophy of Education Society

ISSN

0838-4517 (print)

1916-0348 (digital)

Explore this journal

Cite this document

Bronaugh, R. (1988). Is There Something to be Said for Getting No Respect?

Comment on J.R. Coombs's "Respect for Law: An Educational Object?".

Paideusis, 1(2), 27-34. https://doi.org/10.7202/1073426ar

(C) Richard Bronaugh, 1988

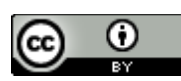

This document is protected by copyright law. Use of the services of Erudit (including reproduction) is subject to its terms and conditions, which can be viewed online.

https://apropos.erudit.org/en/users/policy-on-use/ 


\section{Is There Something to be Said for Getting No Respect? Comment on J.R. Coombs's "Respect for Law: An Educational Objective?"}

\section{Richard Bronaugh, The University of Western Ontario}

Professor Jerrold Coombs noted in this journal 1 that a recent study had found that respect for law and for the rule of law are goals often listed by educators involved in Law Related Education programs. 2 Coombs seeks "to clarify what beliefs, attitudes or dispositions" are implied by such goals and considers what good reasons, if any, there are for adopting them as goals in education. He finds "five different kinds of respect associated with the phrases 'respect for law' and 'respect for the rule of law' (p. 36). I shall exempt from my discussion one meaning of the second phrase, which he calls "Ideal Legal Process Respect" (\#2 of his five kinds of respect), about which I have nothing special to say. ${ }^{3}$ In my comment I will reflect on the relationships among the other four in the course of which I will reach several conclusions not noticed or supported by Coombs. His theory in the end attempts to establish a way to justify teaching students to be critical of the law while at the same time respecting it. He does not seem quite conscious of the potential for paradox here.

One kind of respect (for the rule of law, his \#1) is called "Existence of Law Respect"; I shall call this 'Anarchy Disrespect,' for it is more perspicuous. His "Legal System Respect" (\#3) I shall call "System Self-Respect" because it is granted when one thinks one's own existing system is overall good. "Unqualified Particular Law Respect" (\#4) and "Qualified Particular Law Respect" (\#5) I will call "Blind Respect" and the "Qualified Respect." These two are inconsistent with each other, so they cannot both be fostered in students simultaneously. They relate to particular laws, while \#1 and \#3 relate to the system as a whole. The instructor who teaches respect for law or the rule of law may promote in the classroom, at most, three kinds of respect; these might be, for instance, Anarchy Disrespect, System Self-Respect, and Blind Respect. Coombs resists the final one of these in favour of Qualified Respect.

Anarchy Disrespect is fostered by teaching students to be disposed to behave according to the belief that a law-governed society is better than a lawless or anarchic society. Although Coombs neglects to examine this attitude in Section III where he assesses the others, it is not difficult to see that he would support it as a goal of education. But he correctly notes that dispositions "appropriate to this belief may include willingness to support a legal system even when it 
has substantial defects ..." (p. 36) So in fact to base one's respect for the rule of law upon the avoidance of anarchy will not take one very far towards the critically-minded attitude to particular laws that Coombs favours. I conclude indeed that Anarchy Disrespect gives a reason to uphold any law whatsoever and thus tends to dispose one to Blind Respect and, when considered with anarchy, disposes one to System Self-Respect as well. This is not a point noticed in Coombs's analysis, though it is often noted in critiques of Hobbes whose respect for the rule of law must have been of this nature.

It might be well to reflect briefly upon the idea of teaching respect for law. Consider the difference from merely teaching the law. In this instance one may, as an instructor, work through various sections of the Criminal Code, trying to say what the law is.

In the course of this process, one might-but need not-express admiration for how some sections have been written by the lawmaker or express contempt for how they have been interpreted by the courts, or one might remark upon what good or bad effects have occurred in a wider social and political way through the influence of the statute or its sections. Concretely, one might express respect for the recent Code amendments on sexual assault and seek to show that it is well that one's previous sexual (mis)conduct can no longer be examined on the witness-stand (although some courts have thought this is less than fair to the accused). Equally, other aspects of the Code might on another day come in for sharp criticism, for instance, the several reverse onus requirements in the Code, which shift the burden of proof onto the accused. Depending on what the student "gets" from the course, some parts of the law will receive respect, while others will be viewed with disrespect. Now the question is whether the instructor has been teaching respect for the law.

One thing the instructor may have taught or conveyed, through the very methodology of the course, is a critical approach to the rules of the system, at least of the criminal law. This, in fact, is to teach (or convey something) against Blind Respect (\#4). And it would not be impossible that an attitude of System Self-Disrespect (\#3) could arise in the minds of some students as a result of this process of criticism. So far no respect has been taught, only two kinds of disrespect. But has not Qualified Respect been fostered? If I have understood Coombs correctly, a critical course on the Criminal Code does not alone teach respect for the law. Such a critical process is only an aspect of Qualified Respect, though it does develop "the disposition to take seriously arguments purporting to show the moral deficiencies of individual laws" (p. 35). But there is more to Qualified Respect than criticism; something further must be done in the course.

Coombs's most important conclusion about respect for law is stated thus: "I am persuaded ... laws have moral status or authority 
just because they are laws and that consequently the attitude of qualified particular law respect is the most appropriate attitude (for educators' to take toward laws" (p. 45). Here I understand him to mean that individual laws deserve some respect simply by virtue of their existence, just because they are laws. "Qualified particular law respect" is defined as the "belief [with the associated disposition] that one ought always obey the law except when there is a specific moral justification for disobeying it" (p. 37). This is contrasted with "unqualified particular law respect," or Blind Respect, which is the belief that all laws should be obeyed as one's moral obligation simpliciter. (This belief and the attendant disposition, he argues, should not be taught except in case of political emergency. See p. 42). In other words, educators are justified in normal circumstances in teaching students that law as law has moral status, that this formal circumstance (which is usually termed 'validity') is a reason to obey the law as such, and yet teaching at the same time that there may be other moral reasons (presumably related to a particular law's content) that could in the final analysis justify disobedience.

As one can see, Coombs's theory sets up a tension-a result he does not emphasize-between the formal and the substantive aspects of any particular law. On the formal side, if a law exists, then it can be cited as having moral status as such, i.e., irrespective of content. Having claimed this (p. 45), he then is at once in difficulty. He writes (as above) that "consequently" the qualified sort of respect is appropriately taught. That would not logically follow. But from the fact (if it is one) that validity as law yields moral status or authority, it does not follow that there is needed some further sort of qualification founded on a law's content. Indeed, the conjunction of the two actually has the consequence that there is a potential struggle. But perhaps betler can be made of this. I suggest his thesis be transposed: 'If good reasons support teaching Qualified Respect, then consequently laws have moral status just because they are laws.'

It seems implicit in the theory that the formal status of validity provides an important presumption in favour of always obeying the law as it is. One sees this immediately in how the Qualified Respect thesis is written (p. 37). Disobedience is only justified in the exception: 'one ought to obey except ....' Consider a differently qualified Respect: 'One ought to disobey the law except when there is a moral justification to obey.' (Imagine an educator teaching that in the classroom.) Although this latter thesis appears to be extensionally equivalent to Coombs's qualification thesis, (i.e., it is one with the same truth conditions), it has quite a different sense. He would be inclined to say that it does not show a proper respect for the law. It certainly reverses the presumption of the Qualified Respect thesis and that is the point. Thus it is implicit in Coombs's 
theory that any existing law as law has a leg up in the obedience trials, only to be brought down (if at all) by secondary reflections upon what the law actually demands one do. There is therefore an inevitable presumption favouring another sort of respect which Coombs had also isolated, viz., Legal System Respect (\#3), which I call "System Self-Respect."

About this, Coombs writes that it is a proper educational goal "only if our legal system is deserving of respect .... [E]ducators are warranted in fostering only the degree of respect the legal system merits-no more and no less" (p. 41). This claim fails to take account of, or to stress, the moral respect that every law deserves as such and so fails to note the respect that every system of law also deserves simply by being a set of positive laws. (On this occasion it seems correct to say that when each law individually deserves respect, the set of laws does also.) Yet Coombs might reply here saying simply that being a valid law is a matter of merit too and so this is taken into account. Yet Coombs must not say that validity is merely to be put on the balance. Making validity meritorious (like a kind of content) does not establish law's presumptive position previously implied by Coombs's theses even if it does give some moral authority to each and every existing law. So his characterization of System Self-Respect is not quite right, if his Qualified Respect thesis is right and I have thought this latter was the thesis he wished most to defend in his essay. The point is that Qualified Respect contains a presumption that favours System Self-Respect against any general tendency to have contempt for the system under review.

The outcome is to support in education the fostering of Anarchy Disrespect, System Self-Respect (at least as I think it should be understood for the sake of the theory), and Qualified Respect for particular laws. Coombs resists Blind Respect, but he thinks one might be able to make a good case for fostering it should children be "subjected to non-school influences that induce blind hatred or distrust of our legal system, or were the legal system in danger of imminent collapse because of lack of support ..." (p. 42). This final ground for that conclusion would seem to be the Hobbesian argument that any legal system is better than any anarchy-though Coombs does not actually indicate what the "good case" might be. So it is worth noticing that in this way Anarchy Disrespect is more basic than Qualified Respect which, as he holds, is only or certainly suited to the context of liberal democracy (see p. 42). That is to say, Anarchy Disrespect is always appropriately taught, whereas Qualified Respect is not. Though Coombs takes notice of the suffering anarchy brings, one cannot help but feel that this willingness to teach Blind Respect in a political crisis is somehow tied as well to the not en- 
tirely lucid notion that "laws have moral status or authority just because they are laws" (p. 45). That is not a Hobbesian notion. It is to this that I must now turn for, surely, it is the teaching of Qualified Respect for individual laws that is closest to Coombs' heart.

I have great difficulty seeing how he proves this thesis by the argument he seems to give in its support. I shall try to give the thing a precision his own account lacks. How does one decide whether any sort of respect is defensible as an educational goal? His answer is that respect is to be fostered when "there is good reason to believe that any student, were she to engage in rational consideration of the reasons for and against having that sort of respect las against some other], would acquire the respect" (p. 40). Saying this, he seeks to compare three approaches to the question of whether each law should have respect. One may say that particular laws deserve No Respect (this only means that they lack moral status per se however excellent otherwise); one may say they deserve unqualified or Blind Respect, which means that it is one's moral obligation to obey them period; or one may say they deserve a qualified respect ("Obey unless ...."). Qualified Respect thus establishes a rebuttable presumption in favour of justified obedience to existing rules; this is because validity (it would seem) implies moral authority. Blind Respect allows no rebuttal because law's moral authority always outweighs objections based on content. And finally the No Respect thesis rejects any presumption of justification based on validity either alone or in part. These are the choices that the teacher has. Is there good reason to believe that students, when presented with Coombs's arguments about No Respect, Qualified Respect, and Blind Respect would acquire respect for one of them? I think not.

Coombs argues for the rebuttable presumption thesis, viz., Qualified Respect, against the others, because, first, it best supports a commitment to the benefits of safety and cooperation that legal systems bring; second, it best provides fair, responsible treatment all around; and, third, it best protects "moral autonomy including our right to object to laws on moral grounds" (p.45). Coombs's view, as I said, is that Qualified Respect is what she, the student, would come to support on the strength of these good reasons. Is that plausible? Consider the third point first. To teach Blind Respect (with the disposition to obey) in normal circumstances obviously does not protect autonomy and the right to criticize, so that approach is out. So far so good. And Qualified Respect, by definition, does protect that right but only in rebuttals. However, to teach No Respect also protects autonomy and the right to criticize and disobey. Which of these latter two protects this aspect of autonomy better? It would seem that No Respect must do it better because one does not face any presumption or disposition to the contrary-something that some student possessed of Qualified Respect must overcome. I(2), Spring, 1988 
But I will not hang my critique simply on that claim which does not seem conclusive even if true. Nevertheless, there is something to be said for getting No Respect.

What of fair and responsible treatment all around? (Once again Blind Respect for every law fails, allowing as it does a moral obligation to behave unjustly.) Now Coombs writes: "Qualified particular law respect has the advantage [over no respect] of explicitly committing one to what fairness requires, namely that we share the burdens as well as the benefits ... unless we have good moral reasons for doing otherwise ..." (p. 46). This explicit commitment is presumably the result of the implicit presumption in favour of the existing law. Whether this commitment arises depends upon what sort of incentives are used to move the No Respecter to pull her own weight. It is by no means clear that the power of a belief in law's "moral status" is practically superior to the well-known nonmoral incentives which seek to prevent free riding; hence the prudent desire to avoid liability to punishment may be a stronger force than moral belief to commit the citizen to fair sharing. Between Qualified Respect and No Respect on the matter of commitment to fair sharing, I think that Coombs's case is unproved. There is nothing in his text to settle the point and I get no help by asking whether students, after rational consideration, would acquire one kind of respect but not the other. I see a draw or worse.

The final argument in favour of teaching Qualified Respect for each law is this. Laws convey benefits because they "provide persons with assurance that if they adhere to mutually beneficial rules of conduct, others will also" (p. 45). The Qualified Respect thesis, which supports law as law as it does, gives better assurance of general beneficial conformity than does the No Respect thesis, which gives to law as law no moral authority or status. That is Coombs's position. Once again it depends upon what sort of incentives can be used to make the No Respecter pull weight. However, is not Blind Respect best in this matter when considered by itself? It seems obvious that it must give to all the most assurance. In fact, recall that upon occasions of crisis, a case might be able to be made for fostering Blind Respect. If it will work to secure assurance among students and citizens in crisis, it will work in more ordinary situations as well. Qualified Respect loses again, even if it would be superior to No Respect. But is it superior even to No Respect in securing assurance?

When he states that the law solves the asourance problem he fails to say how. This is the worst sort of neglect because much of his case comes down to this question. What is it that educated people must believe so that all will be assured that they will avoid burdening themselves alone in the dark? Do they have only to believe that others believe that each law, for reason of its being law, 
has a moral status or authority, subject to a moral override through an assessment of the law's demands? How does one get assurance when one believes that others have No Respect for the law? One believes that they conform to law according to their own judgment-or solely on grounds of prudence. So it is compatible, not equivalent, with another view of the reasons there are to obey the law as law. They have to believe that polential free riders will in fact be brought back into line by force before the obedient have foolishly sacrificed without return. Suppose that the teacher teaches about the penalties including the probabilities of being caught (e.g. for house breaking in most Canadian cities). Is this necessarily less effective (to avoid the state of nature and bring the assurance desired) than teaching that law as law has moral status? I am not entirely sure about this choice between Qualified Respect and No Respect (thus understood), but I am absolutely certain that at least assurance is best achieved by fostering Blind Respect-which allows no overriding judgment about justification and obedience.

Let me summarize these points in reverse order. Blind Respect best solves the assurance problem per se: one can expect that blind obeyers will conform as one does oneself, so the system of benefits and burdens will not collapse under excessive free riding. Next, on the matter of commitment to fair sharing, there is probably a draw between No Respect and Qualified Respect. Even if students are taught that law as law has rebuttable moral status, this need not provide superior motivation (or commitment) to be fair as against what physical threats for disobedience regularly achieve. Indeed, if one can talk of commitment among blind obeyers, then Blind Respect may well serve this goal too. Finally, the No Respect thesis seems to allow more readily for autonomous, moral criticism of existing law than either of the others, certainly than Blind Respect. In the end, if I am right, then the Qualified Respect approach is not clearly the one that students would acquire should they consider Coombs's reasons for and against the three choices.

What point has been reached? Consider again the position of Blind Respect in this scheme of argument. Coombs admits that it is the respect of preference in situations of political crisis; it follows that the value of autonomy and the right to criticize the law are conditional on the existence of political stability. Furthermore, Blind Respect solves the assurance problem best, even without emergencies. Also, Blind Respect is compatible with Anarchy Disrespect. Indeed, the latter tends to favour or create the dispositions of the former. Blind Respect is completely compatible with full System Self-Respect; there would tend to be mutual reinforcement in practice. Finally, Blind Respect is happy with the presumption of justification, even though it does not consider it rebuttable. Blind Respect is even hap- 
pier with the idea that law has moral status or authority just in being law. In fact, Blind Respect seems overall to be the strongest, even if imperfectly best in securing the values Coombs holds. Yet this being said, one can be quite sure that Blind Respect would not be the rational choice of informed students.

\section{Notes}

1Jerrold R. Coombs, "Respect for Law: An Educational Objective?" Paideusis, 1(1), (Fall, 1987).

2See Roland Case, On the Threshold: Canadian Law Related Education (Vancouver, B.C.: Center for the Study of Curriculum and Instruction, University of British Columbia, 1985), 125.

${ }^{3}$ It seems to me that this Ideal Process Respect merely states some of the standards relevant to the question of what he calls "Legal System Respect," \#3 